\title{
РЕЦЕНЗІї, ОГЛЯДИ
}

DOI: 10.33402/up.2020-13-357-364

\section{Роман ЛЕХНЮК \\ кандидат історичних наук}

асистент кафедри історії, музеєзнавства та культурної спадщзини

Начіонального університету «Львівська політехніка»

ORCID:http://orcid.org/0000-0003-3758-2019

e-mail: roman.o.lekhniuk@lpnu.ua

\section{[Рец.]: ГАЛИЧИНА РЕАЛЬНА І УЯВНА [на кн.]: Mit Galicji / [pod redakcją naukową Jacka Purchli, Wolfganga Kosa oraz Żanny Komar, Moniki Rydiger i Wernera Michaela Schwarza]. Kraków: Międzynarodowe Centrum Kultury, Wien Museum, 2014. 465 s.}

Поданий у цьому огляді збірник статей був укладений внаслідок однойменної виставки, спільно організованої краківським Міжнародним центром культури $\mathrm{i}$ Віденським музеєм, що тривала з 9 жовтня 2014 р. по 8 березня 2015 р. у Кракові і 325 березня по 30 серпня 2015 р. у Відні. Тема «міфу Галичини» популярна сьогодні не лише серед академічних дослідників з України, Польщі чи Австрії, але й все активніше проникає у сферу масової культури. Привабливість цього міфу та закладений його прихильниками зміст далеко не завжди мають стосунок до реалій Королівства Галичини і Лодомерії з часу 1772-1918 pp. Тому ще актуальнішим стає питання про джерела цього міфу, варіанти його прочитань і різні перспективи, 3 яких його оцінюють, критикують чи глорифікують.

За змістом матеріали книги можна розділити на декілька тематичних блоків, хоча чимало тез і думок наявні відразу в кількох авторів, до прикладу, і Яцек Пурхля, і Еміль Брікс акцентують увагу на паралельному існуванні двох міфів - Галичини як «загиблого королівства», що завдяки своїй етнічній та культурній строкатості було Центрально-Східною Свропою в мініатюрі, а політичний лібералізм творив простір для постання польського й українського П'ємонту поряд з активним розвитком єврейського суспільного і культурного життя; і Галичини - «наполовину Азії», краю бідності й господарського занепаду, який виник ще за існування самої монархії передусім у текстах Станіслава Щепановського і Карла Еміля Францоса.

Тон збірника задає вступна стаття Я. Пурхлі, що є своєрідним нарисом ключових аспектів «міфу Галичини». Дослідник наголошує на незвичному характері самого феномену Галичини - «штучного конструкта австрійської дипломатії» й «ефемириди». Я. Пурхля виокремлює євроінтеграційний контекст цього міфу, який за часів комунізму і згодом відігравав у Західній Україні і Південно-Східній Польщі роль нитки, що зв’ язувала ці терени з європейською цивілізацією. Також 
автор визначає ключові питання щодо модернізаційної ролі монархії Габсбургів в економічній і національно-політичній площині, простежує початки творення «галицького міфу» після 1918 р. у працях Йозефа Рота.

До першого тематичного блоку умовно можна віднести тексти, присвячені появі Галичини як творінню австрійської дипломатії. Ганс-Крістіан Манер у статті «Включення Галичини до габсбурзької монархії у XVIII ст. Політичні і військові аспекти» аналізує геополітичну ситуацію в Центрально-Східній Європі напередодні поділів Речі Посполитої, яка визначила долю Галичини, розглядає політичні проєкти австрійського канцлера Кауніца. Також автор звертає увагу на бачення Віднем ролі нової провінції, зокрема у мілітарній сфері, зважаючи на її прикордонний статус. Питання політичного, господарського і культурного кордонів Галичини дослідив Борис Куцмани у тексті «Про виникнення галицького кордону». Автор наголошує: у 1772 р. Габсбурги анексували території, що ніколи раніше не існували як цілість, це зумовило штучність кордону нової провінції - Галичини, - а його тривкість аж до Першої світової війни забезпечував консенсус між Австрією, Росією і Пруссією. За час свого існування галицький кордон у різних сферах залишив суттєвий слід на ментальній і культурній мапі Центрально-Східної Європи, про що свідчать електоральні симпатії поляків та українців з теренів колишньої Галичини.

Велику групу становлять дослідження міфів - їхньої загальної природи, зв'язку з історією і пам'яттю, конкретних прикладів «галицьких міфів». Теоретичні аспекти міфу з особливою увагою до пов'язаності міфу і війни 3 врахуванням галицького контексту аналізує Юрко Прохасько в тексті «Війна і міф». Автор простежує тісний взаємозв'язок цих двох елементів, доводить, що війна і міф можуть як творити один одного, так і руйнувати. Природу міфів розглядає і Катрін Екер у статті «Міф. Дефініції, значення, входження в історію». Дослідниця наголошує на неможливості логічним і науковим шляхом визначити сутність міфу. Водночас звертає увагу на важливість міфів для функціонування суспільств, що особливо унаочнилось протягом XX ст. Це ж століття продемонструвало не лише привабливість, але й небезпечність міфів. Приклади кількох найпопулярніших колись і тепер міфів аналізує Кшиштоф Заморскі у тексті «Про галицькі міфи». Міфологізація заторкнула не лише політичні, національні й культурні сфери, але й природу краю. Таку ситуацію на прикладі Карпат розглядає Патріс Дамбровскі в есеї «Думки про Карпати, думки про Галичину. Міфологізація галицької землі».

Надважливою часткою «міфу Галичини», яка багато в чому забезпечує його довготривалість і нинішню популярність, є національний аспект. Польська перспектива у книзі представлена насамперед текстом Вальдемара Лазуги «Галичина як “польський” міф». Вороже ставлення щодо Австрії із запровадженням автономії і проголошенням знаної резолюції «при Тобі, найясніший Пане, стоїмо...» змінилось широкими перспективами національного і культурного розвитку, втіленням чого стали блискучі політичні кар'єри батька і сина Голуховських, Юліана Дунаєвського, Казимира Бадені, Міхала Бобжинського, Войцеха Дідушицького та ін. Домінування в інтелектуальному просторі «станьчиківської» школи спричинило утвердження поглядів про необхідність максимального укорінення у сприятливих умовах ліберальної Австро-Угорщини, адже відновлення польської державності було питанням невизначеного майбутнього. Окремо В. Лазуга відзначає важливу 
роль університетських кафедр для успішних політичних кар'єр, що не завжди було можливим не лише на польських землях під владою Росії і Німеччини, а й в інших частинах монархії Габсбургів. Галичина як «польський» міф, на думку автора, насамперед полягала і полягає у цих політичних можливостях, а також культурному й інтелектуальному процвітанні. Ці аспекти затіняють чимало соціально-економічних, освітніх та інших проблем.

Український контекст представлено текстами Ярослава Грицака «Галичина як “український” міф» і Тараса Возняка «Галичина сьогодні». У першій статті дослідник розглянув насамперед два аспекти: непропорційно важливу роль Галичини для польського й українського національних рухів, починаючи з кінця XIX ст., i події XX ст. («орієнталізм» західних спостерігачів і деяких власне галичан, політика II Речі Посполитої, нацистські й комуністичні репресії), що зумовили суттєве затирання пам'яті про габсбурзьку Галичину. Попри всі жахіття ХХ ст., що спіткали землі колишньої австрійської провінції, Я. Грицак акцентує увагу на штучності проєкту Галичини і галичан, особливості населення території колишньої Галичини: i українці, і поляки на цих теренах своїми електоральними симпатіями, консерватизмом, сильним громадянським інстинктом і антикомуністичною позицією мають більше спільного між собою, аніж зі своїми співгромадянами у Польщі й Україні. Водночас автор наголошує на ексклюзивності колективної пам'яті на цих теренах, де польський, український і єврейський наративи через події після розпаду Австро-Угорщини зазвичай конфліктують.

Т. Возняк досліджує чотири українські міфи «Галичини як українського П’ємонту», що активно присутні у сьогоднішньому суспільному дискурсі. Перший 3 них, найбільш «габсбурзький», пов'язаний з важливою культурною і національнополітичною роллю Галичини в українському русі XIX - початку XX ст. завдяки конституційному життю Дунайської монархії. Другий міф стосується ролі краю як джерела формування націоналістичного руху в міжвоєнну добу і його діяльності тоді й під час Другої світової війни. Третій міф - масовий демократичний рух в Галичині на межі 1980-1990-х рр. - яскраво корелюється в пам' яті з крахом Радянського Союзу. Четвертий міф стосується найновішої історії вже незалежної України - Помаранчевої революції 2004 р. і Революції Гідності, або ж Євромайдану, 2013-2014 pp. На думку автора, в обох випадках європейська орієнтація і громадянська активність мешканців Галичини була одним із ключових чинників, що не применшує ролі представників інших частин України. Наприкінці Т. Возняк, як і Я. Грицак, звертає увагу на катаклізми, що спіткали Галичину протягом XX ст., і наголошує на важливому обов'язку сучасних мешканців колишньої Східної Галичини - українців - оберігати багатокультурну спадщину, яку залишила по собі австрійська доба в історії краю.

Невід'ємною складовою цієї спадщини і загалом національного контексту «міфу Галичини» $є$ історія галицьких євреїв. У тексті «Галицькі євреї. Імперські міфи і провінційні ідентичності» Ларрі Вулф зазначає, що на момент приєднання Галичини до монархії Габсбургів євреї становили близько 10\% населення краю (2,6 млн осіб). Протягом ХІХ ст. тут витворився особливий тип «Галіціанерів», або ж галицьких євреїв, що суттєво різнилися від євреїв в інших країнах, насамперед в Російській імперії. Автор стверджує, що для цісаря Йосифа II Галичина була 
tabula rasa - полем для експериментів в дусі освіченого абсолютизму. Однією зі складових цих експериментів правителя було намагання шляхом деконструкції широкої автономії єврейських громад, толеранційних указів, заохочень до займання сільським господарством і торгівлею та ін. інтегрувати євреїв до життя держави значно сильніше, ніж це було за Речі Посполитої. Символом йозефінських перетворень мав стати новий образ єврея - залученого до сучасної економіки, релігійно освіченого і з німецьким прізвищем, - що мав змінити усталену з перших років австрійської влади асоціацію галицьких євреїв з бідністю і занедбанням. Наступним етапом у житті євреїв Галичини, який розглядає Л. Вулф, був час після зрівняння євреїв у правах з іншими громадянами монархії. Насамперед нова доба полягала у широких можливостях політичної активності, а краща правна ситуація витворила у середовищі галицьких євреїв вкрай позитивний образ - черговий «галицький міф»-Франца-Йосифа I. Також автор звертає увагу на соціальну і культурну стратифікацію євреїв Галичини у зв'язку з процесами емансипації і міграції багатьох із них до Відня. Свреї-віденці, вихідці з Галичини, дуже часто з погордою дивились на своїх одновірців, які залишались у найбіднішій частині Австро-Угорщини.

Певною мірою логічним продовженням тексту Л. Вулфа $\epsilon$ стаття Джошуа Шейнса «Творення народу. Галицькі євреї в австрійській державі», де автор насамперед простежує суспільно-політичне життя євреїв Галичини. Дж. Шейнс детально аналізує інтелектуальні витоки, організацію і діяльність різних напрямів (ліберально-просвітницького, консервативного, сіоністичного, соціалістичного), що активно розвивалися після запровадження Конституції 1867 р. Автор зазначає: попри трагедію єврейського народу у XX ст., що максимально знищила сліди багатої культурної і політичної присутності євреїв у Галичині, на початку XXI ст. тип євреїв-«галіціанерів» 3 приписуваними їм «галицькою міфологією» традиційними рисами (спритність, зарозумілість або ж релігійний фанатизм) досі успішно існує серед євреїв, а чимало потомків мігрантів з Галичини до Ізраїлю шукають сьогодні своє галицьке коріння.

До блоку текстів, присвячених національним перспективам, варто віднести i статтю Керстін Йобст «Порозуміння і конфронтації. Національна квестія в Галичині», де проаналізовано позитивні й негативні приклади співіснування українців, поляків і євреїв у Галичині. Наводячи такі події, як польсько-українську угоду 1914 р. щодо сеймової реформи і вбивство Мирославом Січинським намісника Анджея Потоцького у 1908 р., авторка демонструє, що габсбурзька Галичина не була ані втіленням міфу про ідеальне й мирне співжиття, ані вогнищем постійної ворожнечі національних проєктів і націоналізмів. Водночас досліджує змінність політики Відня у національному питанні.

«Міфу Галичини» не можна уявити без врахування бачення краю імперським центром - Віднем. «Де знаходилась Галичина? Кілька рефлексій з віденської перспективи» - текст Вольфганга Коса, у якому він зазначає, що по-справжньому австрійські дослідники вперше після 1918 р. відкрили для себе Галичину лише після цілковитого знищення «галицького світу». Символом цього «перевідкриття» можна вважати, на думку автора, вихід книги Мартіна Поллака «Після Галичини. Про хасидів, гуцулів, поляків і русинів. Уявна подорож Східною Галичиною і Буковиною, або Мандрівка в світ, якого немає». Цікавим елементом тексту В. Коса 
є сюжети, що стосуються двох поштівок на тему переселення галицьких євреїв до Відня. На їхньому прикладі автор демонструє зразки антисемітизму, що був активно присутній у суспільно-політичному житті Австро-Угорщини.

У статті «Галичина як австрійський міф» Еміль Брікс визначає, що з перспективи столиці Галичина завжди становила периферію, віддалену провінцію, де змішувались кордони й ідентичності. Довгий час не було навіть очевидним, чи залишиться цей край під владою Габсбургів, адже за Наполеонівських війн Галичину розглядали як потенційний елемент торгів з Пруссією і Росією. Е. Брікс виділяє два етапи в австрійському трактуванні Галичини: перший - «колонізаційний» - полягав у намаганнях адміністративної інтеграції і германізації, а другий - що настав після 1867 р. - у передачі адміністрації польським елітам. Пишучи про період після розпаду монархії Габсбургів, автор наголошує на зникненні будь-якого зацікавлення Галичиною серед австрійців одразу після 1918 р., а змінюється ситуація лише у 1970-х роках. Розглядає Е. Брікс і сучасний «міф Галичини», визнає його важливу роль для поляків і українців з теренів колишнього коронного краю у контексті ототожнення себе з Свропою і зміцнення культурних зв' язків, зокрема з Австрією. Не останню роль у популярності цього міфу відіграли модернізаційні процеси, що тривали в Галичині протягом панування Габсбургів.

Історії галичан у столиці імперії присвятив свою увагу Вернер Міхаель Шварц у розвідці «Галичина у Відні». На думку автора, Відень для галичан був місцем як перспектив і успіхів, так і розчарувань. Перші насамперед полягали в діяльності у віденському парламенті і можливостях політичних кар'єр. Як приклад автор наводить 1897 р. - «найбільш польський» в історії монархії, коли представники цієї нації одночасно обіймали посади президента міністрів, міністра закордонних справ, міністра фінансів і, звісно, міністра для Галичини. Українські перспективи у столиці автор ілюструє історією освітніх установ, створених для греко-католицького духовенства австрійською владою. В. Шварц простежує політичний та ідейний вплив, який Відень чинив на Галичину і який не завжди був позитивним (наприклад, саме віденському суспільно-політичному клімату приписували ще на зорі XX ст. поширення в краї антисемітизму). 3 єврейською тематикою, на думку автора, були пов'язані і загальні негативні уявлення про Галичину. Це є наслідком згаданого В. Косом ототожнення галицьких євреїв, а звідси і краю з відсталістю і бідністю. Важливим аспектом статті В. Шварца є пункт «Галичина після Галичини», де автор твердить, що Галичина у Відні закінчувалася двічі - із падінням імперії у 1918 р. і з аншлюсом Австрії 1938 р. Остання подія поклала край найпомітнішому, ймовірно, аспекту Галичини у Відні - єврейському. Органічним доповненням тексту В. Шварца є стаття Матіаса Байтля «Подорож шляхами міфу. Галичина у Віденському етнографічному музеї», де автор простежує насамперед інтелектуально-культурні відносини між столицею і північно-східною окраїною держави, описує пов'язані з Галичиною пам'ятки в колекції Етнографічного музею у Відні, зокрема ті, що стосуються організованої в 1904 р. Іваном Франком етнографічної експедиції Бойківщиною та долі біженців з Галичини під час Першої світової війни.

Тематика війни і бачення Галичини з австрійської перспективи є ключовими темами статті М. Поллака «Галичина - це далекий, чужий край». Автор наводить історію свого вітчима, що був солдатом австрійської армії та брав участь у боях в 
Галичині. Власне фрагмент вражень вітчима і винесено у заголовок статті. Війна нерідко ставала для вихідців із західних областей Австро-Угорщини першою змогою познайомитись із Галичиною. І часто ці враження не були позитивними, творячи, як пише автор, враження «культурної пустелі». Очевидно, ключову роль тут відіграли реалії війни - руйнування і смерть. Текст М. Поллака сильно пов'язаний із персональним досвідом і переживаннями. Річ не лише у долі вітчима, але й самого автора. Готуючи свою книгу «Після Галичини. Про хасидів, гуцулів, поляків і русинів. Уявна подорож Східною Галичиною і Буковиною, або Мандрівка в світ, якого немає», він через неможливість потрапити на територію комуністичної Польщі змушений був мандрувати Галичиною завдяки уяві, опертій на літературі. Така єдинодоступна у той час автору методика дала йому змогу відкрити нерівномірність австрійського погляду на історію Галичини, де у фокусі перебувала історія єврейської спільноти, тоді як польська і насамперед українська тематика залишались і часто залишаються на маргінесі. Прикладом «Галичини як краю невідкритих талантів» М. Поллак називає постаті Осипа Турянського, Осипа Маковея і Марка Черемшини.

Із тематикою Великої війни перегукується текст Яна Риделя «Гарнізон Галичина», присвячений мілітарним аспектам габсбурзької Галичини. Як і ставлення Відня до краю загалом, так і відношення військових кіл імперії до Галичини змінювалось протягом XIX ст. Автор акцентує, що каталізатором цієї еволюції були прикордонний статус краю, а відповідно й австро-російські відносини: доки вони залишались дружніми, мілітарна роль Галичини була незначною. Втім, погіршення стосунків між двома імперіями упродовж другої половини XIX ст. призвело до перетворення Галичини на ключовий елемент австрійської військової стратегії у разі війни з Росією. Я. Ридель ілюструє це на прикладі будівництва найсучасніших фортифікацій у Кракові і Перемишлі, що зробило ці міста опорними пунктами австрійської армії. Іншим аспектом теми, проаналізованим автором, $\epsilon$ військова структура Галичини - творення за територіальним принципом армійських полків і пов'язані із цим процеси. Привертають увагу спостереження, присвячені офіцерському корпусу галицьких полків. Офіцери, переважно австрійські німці, критично ставились до галицьких рекрутів, вважаючи їхні бойові якості вкрай низькими. Це перегукується із загалом нерідко критичним ставленням представників центру імперії і iіi західних частин до Галичини і галичан, вже згаданим в огляді текстів М. Поллака i В. Коса. Втім, невдоволення офіцерів мало вагому суб'єктивну складову, адже, як стверджує Я. Ридель, вони не любили служби в Галичині за погані матеріальні умови й важкість проникнення в товариське життя, зокрема через мовний бар'єр.

Не менш важливим за національно-політичні аспекти є модернізаційний дискурс. Цій темі у збірнику «Mit Galicji» присвячено текст Я. Пурхлі «Відень, Краків і Львів на шляху до модерності» і Клеменса Капса «Притулок для вбогих у спіралі часу. Перспективи розвитку Галичини між імперськими інтересами і національними прагненнями». Автор порівнює особливості розвитку Кракова і Львова у контексті модернізаційних процесів у монархії Габсбургів загалом. Спільною рисою для всієї Галичини була ключова роль інституційних чинників і роль Відня як урбаністичного зразка (для Кракова із певним запізненням). Автор вирізняе суттєві розбіжності в шляхах поступу двох найбільших міст Галичини. Особливістю Кракова названо провінціоналізм, клерикалізм, традиціоналізм, етноцентризм і 
кастовість, що стримували розвиток міста. Цю тенденцію змінив лише на початку XX ст. президент міста Юліуш Лео, на діяльності якого автор особливо акцентує. Іншою перешкодою була покладена на місто роль фортеці і збудовані австрійською владою укріплення, створене ними кільце обмежувало територіальне зростання. Противагою до Кракова, на думку Я. Пурхлі, був динамічний розвиток Львова, опертий на капіталістичних відносинах, ролі адміністративного центру й мультикультурному характері, що дало йому змогу на зламі століть стати «найбільш модерним містом на територіях Речі Посполитої».

Одній з найпопулярніших негативних тез «міфу Галичини» - «галицькій нужді»- присвятив своє дослідження К. Капс. Автор простежує зародження цього погляду у працях С. Щепановського, наголошуючи, що тема бідності була невід’ ємною складовою галицького дискурсу з моменту приєднання краю до монархії Габсбургів. Особливістю цього дискурсу був його «цивілізаційний» характер - Відень вбачав у Галичині напівдикий край, який потребував благодатного впливу Заходу. К. Капс зазначає, що це було зумовлено великим впливом німецьких інтелектуалів і їхніх поглядів на Польщу і Литву. Втім, згортання йосифінських реформ звело роль Галичини у господарській структурі імперії до напівколонії і ринку збуту товарів iз промислово розвинутіших регіонів держави. Також важливою частиною тексту К. Капса є роль теми «галицької нужди» у польських і українських дискусіях, спрямованих на пошук покращення економічного й господарського рівня Галичини.

Останнім великим тематичним блоком серед текстів книги є сфера культури. «Алегорія і символ. Галичина у мистецтві» Жанни Комар - текст, у якому досліджено відображені в галицькій і віденській архітектурі уявлення про Галичину і контексти, що впливали на їхню еволюцію. В архітектурних образах міфологічність виявлялась активно, насамперед такі елементи, як неоднозначність у часі й просторі, неясність походження назви краю, різноманітність інтерпретацій. Аналіз різних втілень цих аспектів становить головну частину тексту Ж. Комар. Другою великою темою є роль віденських митців у творенні образів Галичини в самому краї, а також простеження їі образів в архітектурі столиці імперії, зокрема на прикладі віденської Ратуші.

Невід'ємною складовою теми збірника, а значною мірою і джерелом «міфу Галичини», є література. Алоїз Вольдан у статті «Література галицька. Тексти i контексти» окреслює дві теми в галицькій літературі габсбурзької доби, що рівною мірою поєднувала німецько-, польсько- й україномовних авторів - гуцулів і нафтову гарячку. Взаємовпливи авторів і їхніх текстів А. Вольдан простежує на прикладі праць Бальтазара Гакета, Юзефа Коженьовського, Леопольда фон Захер-Мазоха, Гната Хоткевича, Івана Франка, Германа Блюменталя та ін. Він демонструє, наскільки тісно в текстах могли переплітатись економічні, національні й культурні моменти, стереотипи і мультикультурність. Другою важливою частиною статті є аналіз текстів з галицької тематики після зникнення реальної габсбурзької Галичини. Автор наголошує, що після 1918 р. галицька література, по суті, розділилась на окремі національні наративи, виразно між собою відмінні. На прикладі польської та української літератур посткомуністичної доби А. Вольдан демонструє нові шляхи відкриття австрійської Галичини з їі міфами. Натомість Марія Кланська у тексті «Німецькомовна література в Галичині» розглядає тексти на галицьку тематику авторів, які творили німецькою 
мовою і часто дивились на справи з іншої, ніж поляки й українці, перспективи. Авторка, обмежуючись періодом до 1918 р., простежує історію німецькомовного культурного середовища в Галичині, його представників і течії з особливою увагою до постатей Леопольда фон Захер-Мазоха і Карла Еміля Францоса.

Цей короткий огляд текстів книги «Mit Galicji» демонструє тематичну, часову й просторову різноманітність, витворену габсбурзькою Галичиною під час і насамперед після свого існування. Втім, навіть ці статті не охоплюють усіх аспектів «міфу Галичини» (і навряд чи автори ставили собі таку мету). На сторінках книги важко натрапити на історію повсякдення чи тексти про галицьких жінок. Це не $\epsilon$ мінусом оглянутої книги, а радше ілюстрацією невичерпності тем і дискурсів, присвячених Галичині. Важливо наголосити, що особливість «міфу (чи міфів) Галичини» полягає ще й у тому, що кожна історична доба після розпаду АвстроУгорщини творить нові перспективи погляду на габсбурзький світ і Галичину в ньому. I нинішній час не $є$ винятком.

Roman LEKHNIUK $P h D$ Assistant Professor Department of History, Museum Studies and Cultural Heritage Lviv Polytechnic National University ORCID: http://orcid.org/0000-0003-3758-2019 e-mail:roman.o.lekhniuk@lpnu.ua DOI: 10.33402 / up.2020-13-357-364

Halychyna real and imagined. A review on: Mit Galicji / [pod redakcją naukową Jacka Purchli, Wolfganga Kosa oraz Żanny Komar, Moniki Rydiger i Wernera Michaela Schwarza]. Kraków: Międzynarodowe Centrum Kultury, Wien Museum, 2014. 465 s. 